\title{
The environmental state between pre-emption and inoperosity
}

\author{
Luigi Pellizzoni \\ Department of Political Sciences, Pisa University, Pisa, ITALY \\ Corresponding Author E-Mail: luigi.pellizzoni@unipi.it \\ Post-print version \\ Printed version in Environmental Politics 29(1), 2020
}

\begin{abstract}
As a politics of time, pre-emption establishes a 'messianic' relationship between past, present, and future, whereby an indeterminate but certain eschatological event is posited and indefinitely postponed. This gives reality plasticity while obstructing actual change. Pre-emption plays a growing role in environmental politics, building on two types of eschatology, catastrophic or regenerative, and two types of forces preventing its actualization, technological or natural, relying in all cases on state power. To challenge the logic of pre-emption, which overturns the traditional role of apocalypticism as radical contestation of the socio-ecological order, I consider 'inoperosity', which does not mean passivity, or political resignation, but a type of action that refrains from instrumentalizing the world toward relentless achievement and growth. As a concept, inoperosity may help us study emergent social mobilizations and orient the revision of core institutions, such as science, for the realization of which the environmental state is crucial.
\end{abstract}

Keywords: politics of time, pre-emption, climate change, Responsible Research and Innovation, real utopia, inoperosity

\section{Introduction}

Environmental politics is not faring well. Despite worrying signs of climate change, reducing emissions has become an ever more elusive goal. Improved technical and organizational efficiency has not slowed resource depletion. State intervention has remained significant, yet other problems (economic stagnation, security) have taken priority over ecological issues, while market mechanisms and self-regulation (sectoral standards, codes of conduct, critical 
consumerism) have grown in relevance, undermining its authority and capacity (Mol 2016). These and other issues raise the question of the possible presence of structural limits - a 'glass ceiling' - to the transformative power of state institutions and arrangements (Hausknost 2017, 2020), while no other actor seems able or willing to lead in seriously questioning the rush to resource extraction and growth.

Time might be a key element of this impasse. The notion of a 'politics of time' refers to how the relationship between past, present, and future may become a field of power struggles (Kaiser 2015; Opitz and Tellmann 2015). Environmental politics is a case in point, given how it embroils past conditions, present behaviours, and future states of affairs. I address the growing relevance of a peculiar anticipatory politics - pre-emption - as a reason for the limited reach of environmental action. I start by distinguishing pre-emption from other types of anticipation. The 'messianic' relationship it establishes with an indeterminate future gives reality a distinctive plasticity, while obstructing actual change. In the environmental field pre-emption builds on two types of eschatological events, catastrophic or regenerative, and two types of forces preventing their actualization, technological or natural, relying in all cases on state power. However, messianic time is also the time of 'inoperosity', which means not passivity but a type of action that refrains from instrumentalizing the world in pursuit of relentless achievement and growth. This perspective may help us study emergent social mobilizations and orient the revision of core institutions, such as science, for the realization of which the state is crucial.

\section{The structure of messianic temporality}

Time constitutes a special problem for modern societies. Modernity's orientation to the 'new', a futurity conceived as open and actionable, entails the need to identify and select among super-abundant possibilities. Anticipation becomes crucial, taking the form of negation of some of these possibilities (Luhmann 1976).

Anticipation can take different shapes. A classic approach is prevention. Prevention relies on probabilistic risk estimates. These allow one to predict the future without identifying it with only one chain of events. The ontology of prevention is dualistic - on one side the knowing subject, on the other the world acted upon. Its time frame is linear: acting now affects the future state of affairs. 
The limits to risk calculation began to be acknowledged in the 1920s. For John Maynard Keynes and Frank Knight, economic decisions might escape probabilistic estimates, requiring subjective judgements. Yet, they considered incalculable uncertainty as the exception, not the rule. Prevention is still widely applied, also in environmental regulation. However, its primacy started to be challenged in the 1970s, when new perspectives on the biophysical world began to appear.

In ecology, the systemic equilibrium theorized by Eugene Odum's generation is replaced in this period by a new 'ecology of chaos' (Holling 1973), for which there is no spontaneous tendency to biomass stabilization or greater cohesiveness in plant and animal communities, but permanent competition, patchiness, fragmentation. Similarly, in chemistry and physics, attention focuses on 'dissipative structures', thermodynamically open systems characterized by the spontaneous formation of dissymmetry and bifurcations that produce complex, sometimes chaotic, structures (Prigogine and Stengers 1979). In cybernetics, notions of homeostasis and selective openness/closure are supplanted by the idea of emergence, as underlying research on artificial intelligence (Hayles 1999). In these and other fields contingency, disorder, instability become synonymous with vitality and dynamism. As a result, predictive knowledge based on regularities shrinks in scope and appeal.

It is probably not coincidental that the years when this process took off were years of major social turmoil and change: stagflation, energy crisis, mounting environmental threats and protest movements, but also the rise of the post-Fordist industrial model and the beginning of neoliberal reforms. Various scholars have stressed how theories of complexity and disequilibrium, though containing a libertarian critique of Fordist industrialism and 'command-and-control' regulation, provided capitalism with a framework for redirecting socio-ecological instability towards a new regime of accumulation (Walker and Cooper 2011; Nelson 2015). This may sound, and perhaps is, an oversimplification - neoliberalization has hardly been a consistent process (Brenner et al. 2010). Yet, some tenets of neoliberal theories have become a received wisdom, beginning with the idea of crucial limits to prediction and planning faced with social, technical, and ecological complexity, while an influential managerial literature has increasingly celebrated uncertainty, danger, insecurity, volatility, disorder, and non-predictive decision-making as being 'at the heart of what is positive and constructive' (O’Malley 2010, p. 502). 
In the environmental field, one has to register the contemporaneous rise of precaution, as a result of the acknowledgment that threats may elude proper risk assessment. Like prevention, precaution builds on a dualist ontology (Anderson 2010). The world is assumed to proceed 'on its own', should action not take place, or to 'respond' to such action. And, like prevention, the temporality of precaution is linear - indeed all the more so, as threats are usually depicted in terms of irreversible processes. For this reason the imaginary of precaution is typically catastrophic.

A form of anticipation based on a catastrophic imaginary emerged much earlier, during the Cold War: deterrence. Like prevention, deterrence assumes that the world can be known in sufficient detail. Yet, the world is not simply taken to 'respond' to action but is crafted according to what action needs to be effective. Deterrence transforms nuclear annihilation from threat to actual danger (Massumi 2007). The process produces its own cause, and knowledge and world adjust to each other - the ontology of deterrence is non-dualist. Moreover, nuclear proliferation makes the future simultaneously impending and postponed (rather than averted, as with prediction and precaution). As a result, the future backfires on the present differently from the classic performative effect of expectations. With deterrence, looking forward, towards an uncertain future, is replaced by looking backwards, from the certainty of the (catastrophic) future to the action capable of postponing it. The linear arrow of time is replaced by a more complex temporal structure.

This structure is shared with a type of anticipation that has taken momentum since the 1990s (Kaiser 2015): pre-emption. Its rationale is condensed in the following (in)famous statements, one by G.W. Bush, the other attributed to Bush's aide Karl Rove:

If we wait for threats to fully materialize, we will have waited too long. We must take the battle to the enemy, disrupt his plans and confront the worst threats before they emerge [...]. And our security will require all Americans [...] to be ready for pre-emptive action when necessary (Bush 2002, emphasis added).

We're an empire now, and when we act, we create our own reality. And while you're studying that reality—judiciously, as you will—we'll act again, creating other new realities (quoted in Suskind 2004, emphasis added). 
Like deterrence, pre-emption assumes the future actualization of the threat and looks backwards, to what can be done to postpone it. Pre-emption, however, is distinctively more creative than other forms of anticipation. With those the threat is known, though with different degrees of accuracy. With pre-emption it has not emerged yet. Hence, action has to be 'incitatory': 'Since the threat is proliferative in any case, your best option is to help make it proliferate more - that is, hopefully, more on your own terms' (Massumi 2007: § 16). While prevention seeks to save the normal course of events, and deterrence is constrained in a spiralling repetition, pre-emption shares with precaution the idea that the course of events has to be significantly altered, 'creating new facts before it is too late' (Kaiser 2015, p. 174). Yet, contrary to precaution, pre-emption works in a fully plastic world, where knowledge and reality can be adjusted to each other. This eliminates the possibility of error. On one side, being based on potential threats, action cannot be properly proven wrong. On the other, pre-emptive action creates the reality that demonstrates such action was sound from the beginning. Truth is retroactive (Massumi 2007), bypassing, as Bush's aide said, any 'judicious study' of facts. ${ }^{1}$ The unforeseeable ceases to be a problem. It may even become an opportunity, as with the lucrative markets for private security firms and short-term investment that the 'war on terror' opened in Iraq (Anderson 2010).

As with deterrence, therefore, the time of pre-emption is not linear - but neither is it circular, as with many pre- or non-modern conceptions of time. It rather bears resemblance with messianic time. What is this? Giorgio Agamben (2005) describes it as the 'time of the end'. More precisely, it is a present (ho nyn kairos: 'the time of the now', according to St. Paul) defined by a final event (eschaton) and a continuous postponement of such event, enabled by something that holds it back. This is the katechon that St. Paul mentions in the Second Letter to the Thessalonians, as a force that prevents the manifestation of the Antichrist. This force is ambivalent. Since the coming of the Antichrist is necessary to the advent of the kingdom of

\footnotetext{
${ }^{1}$ As Bush claimed in 2005 (quoted in Massumi 2007: § 17), 'some may agree with my decision to remove Saddam Hussein from power, but all of us can agree that the world's terrorists have now made Iraq a central front in the war on terror'. Thus, removing Saddam Hussein was the right thing to do, since in this way Iraq has become what justified such action.
} 
God, it holds evil back, but also the final victory of good. Moreover, its frequent identification (from Aquinas to Schmitt) with the state, bearer of the legitimate monopoly of violence, shows that the katechon may follow a homeopathic strategy: fighting evil with evil itself. This is what happens with deterrence (nuclear weapons against nuclear weapons) and securitarian pre-emption (the threat of bombs addressed with bombs; the attack on western liberties fought by restricting these liberties).

Note, additionally, that messianic time is not chronos but kairos, not sequential deployment but temporal window. In this framework, 'retroactivity of truth' does not mean that the past is reinterpreted in light of the present. This is something historians (and all of us) routinely do. Truth, instead, is retroactive in the sense that the past becomes a place where different things have happened - otherwise the threat could not have been elicited. Pre-emptive truth is not an interpretative but a factual claim, and it is not a matter of hindsight but of foresight - it is in the foreshadowing of the future that the past manifests its actual features. The indeterminate, proliferative character of the threat, moreover, entails a behavioural style neither calculative (prevention), nor prudent (precaution), nor assertive (deterrence). What is required is preparedness for and resilience from the unpredictable - terrorist attacks, financial turmoil, weather extremes, novel or resurgent epidemics, and so on (Cooper 2006; Samimian-Darash 2011).

Pre-emption, therefore, carves out a peculiar window of opportunity. Everything can be transformed (including the past), yet within a threshold that cannot be crossed since action aims precisely to push the eschatological event forward. Everything can be turned upside down to protect a given order. The mutual adjustment of knowledge and reality, moreover, waters down responsibility - there are no proper mistakes, no adverse circumstances from which benefits cannot be drawn, according to a constant experimentalism.

\section{Pre-emptive environmental politics}

\section{Eschaton as catastrophe}

Pre-emption has been mostly discussed with reference to the military and security (Cooper 2006; Massumi 2007; Samimian-Darash 2011), yet it has gained relevance also in the environmental field. Here there is no shortage of apocalyptic narratives building on pollution, 
overpopulation, resource depletion, species extinction, global warming. As 'revelation' of the end of the world, apocalypticism has traditionally underpinned radical contestations of the ruling order. Accordingly, it has played a major role in the green critique of capitalist modernity (McNeish 2017). So far, however, the rise of pre-emption and its reorientation of apocalypticism to conservative purposes have gone mostly unnoticed.

A clue to this reorientation comes from Erik Swyngedouw's considerations about the politics of climate change. The issue, he remarks, is presented as a universal humanitarian threat beyond political dispute, under the assumption of the inevitability of capitalism. Climate politics seeks 'a socio-ecological fix to make sure nothing really changes'; to this purpose the apocalyptic future is evoked to be 'forever postponed' (2010, p. 219, 222).

It is not hard to support these claims. Consider carbon trading. The capitalist logic of accumulation and commodification, arguably a major cause of climate change (overproduction and consumption, 'failure' in recognizing the value of priceless resources), is homeopathically applied to the problem itself, not to solve it (which would mean ending the trade), but rather to modulate its deployment. A peculiar reality is crafted to this purpose. Carbon trading builds on the establishment of a conversion rate between the 'global warming potential' (GWP) of $\mathrm{CO}_{2}$ and other greenhouse gases, so that reducing one of these gases here can be regarded as equivalent to reducing $\mathrm{CO}_{2}$ there. In this scheme GWP is simultaneously symbol and matter, means of exchange and physical phenomenon, cognitive construction and feature of reality. Knowledge and things frictionlessly adjust to each other, pointing to a future that corresponds to a past (base year emission levels) that has retroactively become 'sound'. Nor is it possible to prove climate commodification wrong - the failure of the Kyoto Protocol has led to the even weaker Paris Agreement.

Consider also climate engineering and, in particular, so-called 'solar radiation management' (SRM). The idea is that, if emissions cannot be reduced at the rate and magnitude needed to produce significant effects, then, at least to buy time, a solution that promises to be cheap and quickly productive is to reflect solar radiation - through launching giant mirrors into space, spraying sulphates into the stratosphere, or making clouds brighter by spraying seawater into the air. SRM raises a number of governance questions (see Jinnah and Nicholson 2019 and connected papers). Of particular relevance for the sake of the present discussion is how, given the chaotic character of the atmosphere, it is impossible to predict the actual effect, either 
local or global, of such applications (Macnaghten and Szerszynski 2013). As a 'technical fix', therefore, SRM does not work according to a logic of prevention (which aims to keep a system within predefined parameters), but of preparedness - reacting and adjusting on the spot to the swerves of the system. Similarly to carbon credits, SRM works as a homeopathic katechon. As with the 'war on terror', the idea is that it is better to elicit turbulence rather than wait for its unsolicited manifestation. The actual emergence of such turbulence (such as devastating hurricanes or prolonged draughts in areas where neither had previously occurred) would, moreover, testify that this was an as yet unexpressed possibility. Climate engineers could reject allegations of having elicited disaster, since these phenomena could have occurred in any case. Truth is retroactive.

\section{Eschaton as regeneration}

If the politics of climate change is governed by dystopian imagery, environmental pre-emption takes also the shape of a regenerative eschatology building either on technology or on nature itself. The katechon, therefore, becomes twofold: it either keeps away evil, as with climate politics, or it keeps away good. ${ }^{2}$

Technological regeneration is different from fix - or it is a particular type of fix. While fix usually means applying or improving established technologies, regeneration entails a leap into a new technological world. A number of tropes circulating at academic, policy, and media level convey the idea: for example, 'singularity' (Kurzweil 2005) and 'convergence' (Roco and Bainbridge 2002). The first depicts the moment when technologies overcome human capacities of understanding and control; the second refers to the synergistic combination of nano-bio-info-cognitive technosciences. In both cases, benefits allegedly outweigh dangers: enhanced human physical and mental capacities, tightened human-machine interface, revolutionized medicine, automation of risky or boring tasks, environmental sustainability (bioremediation, energy efficiency). Yet, according to these and comparable narratives, we

\footnotetext{
${ }^{2}$ As stressed by Taubes (2004), since its identification with the state - bulwark against chaos - the katechon loses its original ambivalence, as evil and good-averting force: only the dystopian element of Christian eschatology remains. The peculiarity of environmental pre-emption, then, is that it recovers the utopian side of eschatology while disconnecting it from the dystopian side.
} 
are always on the edge of the new world, never properly there. The katechon here takes the face of mistrust, vested interests, irrational fears, or homeopathically consists in the route itself - more research, more money is needed for the final leap.

These narratives fulfil major political purposes. Hype and promise obscure the continuation and intensification of business as usual. Consider agricultural biotechnologies, where appropriation and commodification (of biodiversity and scientific research) is narratively supported by eschatological claims, such as dramatic leaps in productivity bringing about the end of hunger, or the optimization of energy and chemicals leading to clean industrial agriculture. Simultaneously, corporate storytelling depicts biotech as the continuation of what humans did for thousands of years, or nature always did, "the "technology" in these practices [being] nothing more than biology itself, or "life itself"' (Thacker 2007, p. xix). The past and future of agriculture, and indeed of life itself, are realigned with the biotechnological present. Biotech makes nature what it always was - or could have been. As a result, GMOs can be depicted, and legally protected, as indistinguishable yet simultaneously different (more usable, valuable) from natural entities.

Consider also the concept and policy framework of 'Responsible Research and Innovation' (RRI). RRI is described as 'a transparent, interactive process by which societal actors and innovators become mutually responsive to each other with a view to the (ethical) acceptability, sustainability and societal desirability of the innovation process and its marketable products' (von Schomberg 2013, p. 63). The idea, not new, is to shape technology before technological 'lock-in' sets in. Novelty lies in the proactivity of the approach (the emphasis is on innovation rather than risk) and - on paper - in the opening of inquiry to 'purpose' questions (rationale, distributive effects, alternatives). Yet RRI has inherently pre-emptive aspects.

The earlier its intervention, and the broader its aspiration, up to detecting and steering real 'game changers', the more RRI should be prone to the 'Collingridge dilemma': at an early stage of development it is easier to shape technologies, but it is more difficult to anticipate their impact. In fact, notes Alfred Nordmann, predicting real novelty and its effects is impossible: 'This imagined future is a different world, inhabited not only by different technologies but [as a result] inhabited by different people too' (2014, p. 89). Yet, it has been noted, this objection holds only according to a linear approach to time; the rationale of RRI is 
instead to turn the future 'to achieve some goal in the present, whether to discover other options, more clearly articulate a current state, or consider the futurity of a set of actions' (Selin 2014, p. 104). RRI, in other words, institutionalizes the relation to time discussed by some psychologists, whereby past, present and future 'fold backward and forward like Japanese origami, [...] collapse onto each other, emerge from each other and constantly determine each other as we construct and reconstruct both past and future in the present, and the past and future construct the present' (Johnson and Sherman 1990, p. 482). In this account the Collingridge dilemma disappears. The leap is indeterminate, yet certain, the impossibility of consequential reasoning promising and postponing it indefinitely. Societal preparedness for the unexpected can be elicited while reproducing the status quo within which the unexpected itself is contained.

Marketization, for example, remains the default option for the diffusion of innovation, a major goal of RRI being to speed up the transfer from bench to market (Zwart et al. 2014). Social divisions over technological change are depicted as between initiates and laypeople, rather than between contrasting interpretations of the public good (Grinbaum and Groves 2013), which arguably rules out real 'purpose questions'. The 'mutual responsiveness' of innovators (typically corporations or research institutions) and stakeholders (typically fragmented groups of end users) is pleaded while leaving unaddressed their differentials in agency, with consequent likely increase in what Ulrich Beck called 'organized irresponsibility'. 'We shared the choice, we share the blame', the innovator can say in case of unfortunate outcomes. Or, possibly, there is no blame at all, since the realignment of past, present, and future makes any outcome 'sound' by definition. Think, for example, if sterility of GM crops extended to non-GM ones, or, as seems already to be happening, super-resistant pests developed as a result of massive use of pesticides allowed by GM crops' capacity to withstand them. Calling these 'terrible mistakes', the innovator could claim, is incorrect; they are actualizations of latent possibilities, perhaps useful for other purposes.

RRI is the latest attempt to address what in governmental and corporate parlance is people's 'resistance' to innovation, a narrative where the katechon is usually identified in the lack of understanding of science (Felt and Wynne 2007). Yet, the katechon is arguably RRI itself. Proper innovation threatens the ruling order, and the more such order relies on innovation, the more it needs to find ways to domesticate it. Contrary to official claims, the actual mission of 
RRI seems to be postponing real 'game changers' forever.

\section{Pre-emption as problematization}

Though pre-emption fulfils the task of reproducing the current socio-ecological order, it would probably be wrong to reduce it to a capitalist strategy. Foucault's notion of 'problematization' may be more suited to the case. By problematization, Foucault (2001) means a framework of meaning that comes to dominate a historical period, being shared by otherwise distant, even politically opposite, standpoints. That this may apply to pre-emption is suggested by a comparison of two recent Manifestos: the 'ecomodernist' and the 'accelerationist': the first synthesises the pro-capitalist, 'post-environmentalist' agenda promoted by an American think tank, the Breakthrough Institute; the second comes from post-Marxist scholarship and indicates an avenue for overcoming capitalism and its socio-ecological destructions.

The Ecomodernist Manifesto 'affirm[s] one long-standing environmental ideal, that humanity must shrink its impacts on the environment to make more room for nature, while reject[s] another, that human societies must harmonize with nature to avoid economic and ecological collapse' (Breakthrough Institute 2015, p. 6). Farming, energy extraction, forestry, settlement and other activities must be intensified via application of ever-more powerful technologies to decouple society from the biophysical world, so that ecological crises can be overcome, growth can proceed, and elements of such world can be 'spared' for aesthetic or spiritual reasons. In this 'good Anthropocene', capitalist socio-ecological relations can survive and expand. The eschaton here is the end of, or liberation from, nature, in the sense of its full humanization (see Arias-Maldonado 2013), while the katechon that postpones this moment is traditional environmentalism or vested interests fostering catastrophism and technophobia. Ecomodernism may look like a reiteration of technocratic arguments, with their typically scant empirical support and neglect of the 'rebound effect' (more efficiency in the use of a resource typically leads to more use of that resource, or connected others). Novel, however, and powerfully pre-emptive, is the redefinition of nature as an internal differentiation of technology (or capital?) - something deliberately, and provisionally, 'let be'. In this sense, finding contradiction in the claim that we live in the age of the end of nature, and simultaneously that technological intensification leaves more room to nature (Kallis 2017), or 
stressing that the ontology of ecomodernism is not suited to the Anthropocene, where humans can no longer be conceived as being 'alone on stage' (Latour 2015, p. 223), means missing the crucial point about the ecomodernist case. Technological intensification surely does not lead to a decoupling from, but to an increasing intimacy with, biophysical materiality; yet for ecomodernists it is this very materiality that is (to be) decoupled from its autonomous existence.

If we turn to the Manifesto for an Accelerationist Politics, we find more than a passing similarity with ecomodernism. According to its authors, the goal of the left should not be to reverse the growing technical and organizational complexity of capitalism by means of 'folk politics' (localism, primitivism, immediacy, affectivity), but to build on and accelerate the gains of capitalism to overcome its 'value system, governance structures, and mass pathologies', which dramatically limit 'the true transformative potentials of much of our technological and scientific research' (Williams and Srnicek 2013, § 3.6). The potentials of automation, big data and logistics for building a post-capitalist, post-work society are especially stressed (see also Srnicek and Williams 2015). The imagined society, however, looks as (allegedly) decoupled from nature as the ecomodernist one: 'liberation from work' means liberation from capitalist relations but also from material limits to human achievements. In this sense, the accelerationist eschatology envisages the end of capitalism but also, and first of all, of nature - not by chance, after a token evocation of the coming ecological apocalypse, nature virtually disappears from the argument. Similarly to ecomodernists, moreover, accelerationists give poor empirical support to their claims and neglect the rebound effect, to which a reduction in work time is not immune (if production levels remains unchanged, environmental impacts are unlikely to decrease). While Srnicek and Williams blame 'folk politics', the katechon hampering the overcoming of capitalism can be argued to lie in the homeopathic character of acceleration itself, to the extent that, to 'traverse' capitalism, one accepts and relaunches its logic - isn't the replacement of labour with machine the eternal capitalist dream?

That pre-emption may constitute the dominant problematization of the present is suggested also by observing that the argument about a regenerative eschaton does not build only on technology but also on nature itself. At least two variants of this case can be detected in recent academic literature. 
The background of the first is the post-workerist thesis about cognitive capitalism: the more capitalism builds on knowledge and innovation, the more the production of surplus value shifts from machines to the linguistic and communicative abilities of humans, their creativity, affectivity and ethicity (Virno 2004; Moulier Boutang 2007). These capacities, it is claimed, are formed outside production processes. This offers room for enacting post-capitalist relations, orienting innovation accordingly. Cognitive labour, in other words, would be simultaneously central to capital accumulation and to the possibility of radical change. This thesis has been extended to the 'infinitely productive' potentiality of non-human nature, 'as something presupposed, but not produced, by state and capital' (Braun 2014, p. 11). In particular, the expanding economy of 'ecosystem services' - the benefits biophysical systems give to humans, from resource provision to regulative and supporting functions like carbon sequestration, waste decomposition, soil formation, crop pollination (Millennium Ecosystem Assessment 2005) - would indicate the growing relevance of 'self-organizing dynamics and regenerative social-ecological capacities outside of the direct production processes' (Nelson 2015, p. 462). Again, capital increasingly relies on something it cannot control and, being extraneous to its logic, is bound to engender a radical transformation. Yet the promise of creativity and vitality - of the creativity of life - appears continuously postponed. Indeed, the katechon seems to lie in creativity and vitality themselves, as continuously integrated in capital relations: on one side human creativity is not free-floating but is affected by precarious work conditions and prescriptive cultural and organizational models of fulfilment, achievement, and reward (Dardot and Laval 2014); on the other, the more the 'immense but underestimated economic value' (FAO 2012) of ecosystem services is recognized, the more the self-organizing, regenerative capacities of nature become the object of appropriation and commodification. Measurement and monetization of ecosystem services may create continuous tensions and contradictions (Robertson 2012), and the very notion of 'valuing nature' may be controversial (Turnpenny and Russel 2017), yet this is not hampering the expansion of the sector.

Another variant of 'natural' eschatology builds on the notion of 'geopower' (Grosz 2011), or 'geological politics' (Clark and Yusoff 2017). In this case the claim is that, if human agency has scaled up at planetary level, geological forces affect in their turn both social formations and political agency. This may seem a platitude: the role of geological conditions in human 
affairs have long been recognized, a recent take on the theme being Timothy Mitchell's (2011) discussion of how fossilized hydrocarbons have affected the evolution of modern democracy. Yet, in the framework of burgeoning acknowledgments of the agential powers of materiality (Coole and Frost 2010; Pellizzoni 2016), geological processes are seen as both the premise or background of life on the planet and a barrier to human agency - not so much for their temporal scale, as for their constitutive instability, their discontinuities, the abrupt system changes to which they are susceptible beyond any possibility of prediction, let alone control. Politics, then, has to acknowledge the 'indifferent', non-negotiable character of these features, which geological phenomena share with biological manifestations of 'inhuman' nature, such as viruses and bacteria (Hird 2009). Or, 'negotiating' with a nature impervious to human concerns 'involves actualizing some of the potential of forces that will always exceed our understanding and utilization' (Clark 2017, p. 228). This, it is claimed, means grounding politics on trial and error, flexibility, 'ongoing creative experimentation' (Clark and Yusoff 2017, p. 18). Again, the call is for preparedness and resilience. And, again, action is conceived to play an 'incitatory' role on the unpredictable. True, in this framework regeneration does not stem from technology but from nature's capacity to reshuffle the terms of survival, while the pre-emptive effect is produced by a hypo-agential subject, symmetrically opposed to the hyper-agential one of ecomodernism and accelerationism. In political terms, however, the outcome is similar. Faced with overarching natural forces, there can be no actual failure, no proper mistake, only ever-adjustable responses. Experimental politics cannot be proven wrong. ${ }^{3}$

\section{Pre-emption, inoperosity and the state}

To sum up, a peculiar anticipatory politics based on a messianic temporal structure has gained relevance in the environmental field. Contrary to its traditional role, apocalypticism becomes

\footnotetext{
${ }^{3}$ To the extent that pre-emption has become the dominant governmental logic, a logic aimed at making reality ever-more malleable to infinitely extend the status quo, experimentalism loses any 'progressive' thrust (as typical of the pragmatist tradition). The same applies to reflexivity, a virtue in which hopes are still placed (Dryzek 2016; Pickering 2019) despite modernity obstinately refusing to go in the direction Ulrick Beck wished thirty years ago.
} 
instrumental to conservative purposes. Pre-emption sets a dramatic change in the future, postponing its actualization through the mobilization of a variety of forces. A 'kairological' window opens, where everything can be made different to ensure that the socio-ecological order remains the same.

It is important to note that in all the cases addressed, and arguably in many others, pre-emptive politics relies on state (or state-backed institutions') power, as being alone capable of enforcing appropriate regulatory frameworks - as with carbon trading and biotech patents - or legitimizing and supporting strategic choices, like those entailed by SRM and RRI programs, or any sort of experimental politics. Even ecomodernists, who subscribe to the neoliberal critique of the 'planning fallacy of the 1950s', assign a strong role to the state 'in addressing environmental problems and accelerating technological innovation' (Breakthrough Institute 2015, p. 30).

Pre-emptive politics, therefore, can be argued to constitute a major component of the glass ceiling to the environmental state. Coming to this conclusion was my basic goal here. The question of whether and how such politics can be challenged cannot be properly addressed here. However, to outline a direction of inquiry, let us start by recalling how, for Foucault (2007), critique cannot aspire to a transcendent vantage point, but has to build on the historical situation, the feeling of unease and dismay for the ways in which, and the purposes for which, one is governed, to devise 'unthinkable' alternatives. These are what Erik Olin Wright (2010) calls 'real utopias': not fantasies but pathways to change that move from one's own lived experience, the available grammar of meanings. It is good to stress, then, that messianic time can be endless postponement, but also opportunity for change. Messianic time is the time of people who, living in 'the time that remains between time and its end' (Agamben 2005, p. 62), are remnant themselves - not part or residual, but excess with respect to ruling distinctions and hierarchies (slave/free, circumcised/uncircumcised, man/woman, human/nonhuman, mind/body, living/non-living). For this reason, according to St. Paul, messianic time offers the possibility of living in the form of the 'as not', a condition where differences lose their relevance. This claim has often been read as an invitation to accept one's own mundane condition, giving up emancipatory projects. Yet, as long as it contests relations of domination, the Pauline 'as not' has major political implications. Revolution, Walter Benjamin famously said, more than turning things upside down (which ends up 
reproducing domination) means interrupting the course of events, pulling the emergency brake in the derailing train of history. It means, we could say, doing things differently before doing different things. Indeed, considering how pre-emptive politics is effective in integrating alleged 'counter-powers', a subtractive modality of action might have more chances of success.

To designate this modality, a varied scholarship (from Kojève to Bataille, from Blanchot to Nancy) has elaborated on the notion of 'inoperosity'. Agamben defines it as 'an activity that consists in making human works and productions inoperative, opening them to a new possible use' (2014a, p. 69), which means de-instrumentalizing the world and oneself, breaking free from the compulsion or coercion to achieve and grow. For Agamben this is possible because the human 'is the animal who is capable of its own impotentiality' (2014b, p. 487, translation modified), that is, of leaving its potential unactualized. A historical example comes from Franciscans, who accounted for their 'poverty' as the abdication to any right over things, which could therefore only be factually used, as with animals, according to need (Agamben 2013). The feast is also a classic example of inoperative praxis, being the day where "what is done - which in itself is not unlike what one does every day - becomes undone, is rendered inoperative, liberated and suspended from its "economy", from the reasons and purposes that define it during the weekdays' (Agamben 2014a, p. 69). The same applies to play.

Degrowth, as a social movement and an academic field, can be regarded as a contemporary way of conceiving and enacting inoperosity, to the extent that it points to a politics of self-limitation, of 'choosing not to' (Kallis 2017, p. 48) pursue goals that could be pursued, realize things that could be realized, achieve performances that could be achieved, appropriate things that could be taken over, and so on. Some degrowth scholars refer to Bataille's notion of dépense (D'Alisa et al. 2015) - unproductive expenditure or 'waste' set against instrumental rationality and the capitalist logic of scarcity, accumulation and commodification. This notion, however, is possibly too focused on the actualization of human potential to offer ground for a renewed environmental politics. For dépense, the feast is orgiastic excess, doing more and else, rather than turning the same, or less, to different purposes. Moreover, from an ecological perspective, scarcity is not (only) an effect of capitalist relations, but (also) a way of relating with nature by setting and accepting limits to 
one's will. ${ }^{4}$ Similarly, one should be cautious about regarding inoperosity as synonymous with 'care'. In recent philosophical and social science accounts of socio-material entanglements this expression conveys an affective orientation that is equated too quickly with respect and non-domination (Puig de la Bellacasa 2011) - at least, if one thinks of the enterprising, responsible citizen elicited by neoliberal regulation of corporeality (Rose 2007), or how post-Fordist economy thrives on jobs focused on relationality and emotions (Federici 2012). That the notion of inoperosity has primarily a normative, rather than affective, content should therefore represent a critical advantage.

These remarks, however, indicate that the notion needs elaboration. Such elaboration cannot be only theoretical. It should fertilize and be fertilized by empirical research. The concept, for example, can be applied to emergent mobilizations. Degrowth activism is part of a broader wave of 'prefigurative politics' (Yates 2015), where what is done expresses and actualizes the very goals of action. In this sense prefiguration is opposed to pre-emption. While pre-emption anticipates the future to hinder its realization, prefiguration implants the future in the present in the form of the example. From negative, anticipation becomes affirmative. The paralyzing drama of eschatology recedes, giving salience to the transformative potential of the messianic moment. These movements work at the level of the body and materiality to build alternative forms of community organization and material flows, away from the circulations of capitalism (Schlosberg and Coles 2016); in the global South, the struggles against dams, oil extraction, mining, deforestation, GM crops; in the North, food and energy movements (farmers' markets, community-supported agriculture, solidarity purchase groups, open source seeds communities, community energy initiatives), the 'new domesticity' of crafting and making (canning, sewing, mending), time banks, community-based credit systems, urban gardening and other activities aimed at (re)constituting a tie between people, things and places. These mobilizations follow a logic of interstitial transformation (Wright 2010). Rather than seeking to break with the dominant order, wait for its collapse, or adapt in the hope of

\footnotetext{
4 In this sense, a collective feast or leaving a forest idle can both 'burn capital out' (D'Alisa et al. 2015, p. 217), yet they are not equivalent in terms of material flows, relations with things. Moreover, they do not necessarily burn capital out: organizing leisure time is lucrative and a forest left idle can become an equally lucrative ecosystem service.
} 
changing it from within, they work at its margin. Under what conditions this may correspond to eroding its clutch on socio-material relations is a question of major relevance. A first step to answering is to distinguish, with the help of the notion of inoperosity, between actual prefigurations and activities that work as relief valves of social tensions, substituting the market and the state in the provision of goods and services (Bosi and Zamponi 2015). Prefiguration does not necessarily mean something outwardly different. Even in conventional everyday practices doing may coincide with being rather than the opposite, as with the urge to growth and achievement. ${ }^{5}$ For Franciscans, this meant poverty, and poverty meant 'mere' use, according to need. A clue to 'proper' prefiguration, then, may be whether things are just used, rather than appropriated, exploited, enhanced, valorised. There are also novel practices, such as open software or seeds movements, or 'frugal' innovation (products and processes reworked to reduce material and financial costs, rather than increase performance or profit: see Khan 2016). The clue, again, is whether novelty lies in the goals - away from growth aspirations - rather than, or before, the means.

Social effervescence may significantly contribute to revitalizing the environmental state, stimulating the revision of major institutions. I mentioned open software/seeds and frugal innovation. Both bring science to the fore. We have seen its centrality to pre-emptive politics. The idea of inoperosity as doing things differently, acting in the world without considering everything - in Heidegger's famous definition - a 'standing reserve', leads to a call to nurture real utopias of a different science. 'Participatory plant breeding' might be an example: researchers cooperate with farmers to adapt varieties to local ecosystems, rather than the opposite (Ceccarelli and Grando 2009). More generally, the aim of novel approaches should not be to bring about a science as 'successful' as the present one but purified of its drawbacks - if it has to pull off exactly the same material results, 'the alternative is not going to be an alternative' (Hacking 2000, p. S64) - but to conceive of different goals and criteria of success, to which different theories, concepts, and methods are likely to be suited. Thinking of another science as a real utopia means taking steps regarding science education, organization, and funding, to which the state is crucial. For example, there are concrete reasons (cultural, economic, political) why genetic engineering has been vastly privileged over agroecology in

\footnotetext{
${ }^{5}$ Agamben (2013) calls this coincidence 'form-of-life'. For an application to occupations see Bulle (2018).
} 
terms of resources, professional careers and so on, reasons that have nothing to do with their stance as scientific and technological approaches (Vanloqueren and Baret 2009). Only the state can reorient research to studying and developing sustainable agroecosystems, repurposing gene technologies accordingly, which means, among other things, supporting research programs that pay attention to multifactorial causal mechanisms, challenging the present dominance of reductionist approaches.

\section{Conclusion}

I have argued that the 'glass ceiling' to environmental transformation is due, to an important, perhaps decisive, extent, to an anticipatory politics that simultaneously posits and postpones catastrophe or regeneration, pre-empting actual change. I have in the last section given a clue to the usefulness of a concept, inoperosity, which refers to the possibility of radical change. Inoperosity can work as a conceptual tool for assessing the potential of emergent mobilizations grounded on a material, embodied contestation of the socio-ecological order that pre-emption seeks to maintain against all odds, and for orienting the revision of core institutions, such as science. The issue is complex, and further theoretical elaboration and extended empirical research are required to understand the conditions under which an inoperative praxis may effectively challenge pre-emptive environmental politics, opening the way to a sustainable society.

\section{Acknowledgments}

I thank two anonymous reviewers for their insightful comments, critiques and suggestions on an earlier version, which led me to rework several points of the argument. The final result is of course my own responsibility. Many thanks also to Marit Hammond and Daniel Hausknost for organizing the workshop at the 2017 ECPR Joint Sessions, Nottingham, where the first version of the paper was presented, and all the participants for their very valuable comments.

\section{References}

Agamben, G., 2005. The time that remains. Stanford: Stanford University Press

Agamben, G., 2013. The highest poverty. Stanford: Stanford University Press. 
Agamben, G., 2014a. What is a destituent power? Environment and Planning D, 32(1), 65-74. Agamben, G., 2014b. The power of thought. Critical Inquiry, 40(2), 480-491.

Anderson, B., 2010. Preemption, precaution, preparedness: anticipatory action and future geographies. Progress in Human Geography, 34(6), 777-798.

Arias-Maldonado, M., 2013. Rethinking sustainability in the Anthropocene. Environmental Politics, 22(3), 428-446.

Breakthrough Institute, 2015. An Ecomodernist Manifesto. Oakland, CA: Breakthrough Institute. Available from: http://www.ecomodernism.org/manifesto [Accessed 30 March 2016].

Bosi, L. and Zamponi, L., 2015. Direct social actions and economic crises. Partecipazione e Conflitto, 8(2), 367-391.

Braun, B., 2014. New materialisms and neoliberal natures. Antipode, 47(1), 1-14.

Bulle, S. 2018. Formes de vie, milieux de vie. La forme-occupation. Multitudes, 71, 168-175.

Brenner, N., Peck, J. and Theodore, N., 2010. Variegated neoliberalization: geographies, modalities, pathways. Global Networks, 10(2), 182-222.

Bush, G.W., 2002. President Bush delivers graduation speech at West Point, June 1. Available from: https://georgewbush-whitehouse.archives.gov/news/releases/2002/06/20020601-3.html [Accessed 11 January 2018].

Ceccarelli, S. and Grando, S., 2009. Participatory plant breeding. In: M. Carena (Ed.), Cereals. Handbook of Plant Breeding, Volume 3. New York, NY: Springer, 395-414.

Clark, N., 2017. Politics of strata. Theory, Culture \& Society, 34(2-3), 211-231.

Clark, N. and Yusoff, K., 2017. Geosocial formations and the Anthropocene. Theory, Culture \& Society, 34(2-3), 3-23.

Coole, D. and Frost. S., eds., 2010. New materialisms. Durham, NC: Duke University Press.

Cooper, M., 2006. Pre-empting emergence. Theory, Culture \& Society, 23(4), 113-135.

D’Alisa, G., Kallis, G. and Demaria, F., 2015. From austerity to dépense. In: G. D’Alisa, F.

Demaria and G., Kallis, eds. Degrowth. London: Routledge, 215-220.

Dardot, P. and Laval, C., 2014. Commun. Essai sur la révolution au XXI siècle. Paris: La Découverte.

Dryzek, J.S. 2016. Institutions for the Anthropocene: governance in a changing Earth system. 
British Journal of Political Science, 46(4), 937-956.

FAO, 2012. Payment for Ecosystem Services. Available from: http://www.fao.org/3/a-ar584e.pdf [accessed 24 August 2017].

Federici, S., 2012. Revolution at point zero: housework, reproduction, and feminist struggle.

Oakland, CA: PM Press.

Felt, U. and Wynne, B., eds., 2007. Taking European knowledge society seriously. Luxembourg: European Communities.

Foucault, M., 2001. Fearless Speech. Los Angeles: Semiotext(e).

Foucault, M., 2007. What is critique?, In: S. Lotringer, ed. The politics of truth. Los Angeles: Semiotext(e), 41-82.

Grinbaum, A. and Groves, C., 2013. What is 'responsible' about responsible innovation? Understanding the ethical issues. In: R. Owen, J. Bessant and M. Heintz, eds. Responsible Innovation. Chichester: Wiley, 119-142.

Grosz, E., 2011. Becoming undone. Durham, NC: Duke University Press.

Hacking, I., 2000. How inevitable are the results of successful science? Philosophy of Science, 67 (Proceedings), S58-S71.

Hausknost, D., 2017. Greening the Juggernaut? The modern state and the 'glass ceiling' of environmental transfomation. In: M. Domazet (ed.), Ecology and Justice: Contributions from the margins. Zagreb: Institute for Political Ecology, 49-76.

Hausknost, D. 2020. The environmental state and the glass ceiling of transformation. Environmental Politics, 29(1): [this issue].

Hayles, N.K., 1999. How we became post-human. Chicago: University of Chicago Press.

Hird, M., 2009. The origins of sociable life: evolution after science studies. New York: Palgrave MacMillan.

Holling, C.S., 1973. Resilience and stability of ecological systems. Annual Reviews of Ecology and Systematics, 4, 1-23.

Jinnah, S. and Nicholson, S. 2019. Introduction to the Symposium on 'Geoengineering: Governing Solar Radiation Management'. Environmental Politics, 28(3), 385-396.

Johnson, M. and Sherman, S. 1990. Constructing and reconstructing the past and future in the 
present. In: E.T. Higgins and R.M. Sorrentino (eds.), Handbook of Motivation and Cognition:

Foundations of Social Behavior. Volume 2. New York: Guilford Press, 482-526.

Kaiser, M., 2015. Reactions to the future: the chronopolitics of prevention and preemption.

Nanoethics, 9, 165-177.

Kallis, G., 2017. In defense of degrowth. Available at: http//:indefenseofdegrowth.com [Accessed 5 November 2017].

Khan, R., 2016. How frugal innovation promotes social sustainability. Sustainability, 8(1034).

Kurzweil, R., 2005. The singularity is near. New York: Viking.

Latour, B., 2015. Fifty shades of green. Environmental Humanities, 7, 219-225.

Luhmann, N., 1976. The future cannot begin: temporal structures in modern society. Social Research, 43(1), 130-152.

Macnaghten, P. and Szerszynski, B., 2013. Living the global social experiment: an analysis of public discourse on solar radiation management and its implications for governance. Global Environmental Change, 23(2): 465-474.

Massumi, B., 2007. Potential politics and the primacy of preemption. Theory \& Event, 10(2), n.a. McNeish, W., 2017. From revelation to revolution: apocalypticism in green politics.

Environmental Politics, 26(6), 1035-1054.

Millennium Ecosystem Assessment, 2005. Ecosystems and human well-being; synthesis.

Washington, DC: Island Press.

Mitchell, T., 2011. Carbon democracy. London: Verso.

Mol, A.P.J., 2016. The environmental nation state in decline. Environmental Politics, 25(1), 48-68.

Moulier Boutang, Y., 2007 Le capitalisme cognitif. Paris: Editions Amsterdam.

Nelson, S., 2015. Beyond the limits to growth: ecology and the neoliberal counterrevolution. Antipode, 47(2), 461-480.

Nordmann, A., 2014. Responsible innovation, the art and craft of anticipation. Journal of Responsible Innovation, 1(1), 87-98.

O’Malley, P. 2010. Resilient subjects: uncertainty, warfare and liberalism. Economy and Society, 3(4), 488-509. 
Opitz, S. and Tellmann, U., 2015. Future emergencies: temporal politics in law and economy. Theory, Culture \& Society, 32(2), 107-129.

Pellizzoni, L., 2016. Ontological Politics in a Disposable World: The New Mastery of Nature. London: Routledge.

Pickering, J. 2019. Ecological reflexivity: characterising an elusive virtue for governance in the Anthropocene. Environmental Politics, 28(7), 1145-1166.

Prigogine, I. and Stengers, I., 1979. La Nouvelle Alliance. Paris: Gallimard.

Puig de la Bellacasa, M., 2011. Matters of care in technoscience: assembling neglected things. Social Studies of Science, 41(1), 85-106.

Robertson, M., 2012 Measurement and alienation: making a world of ecosystem services.

Transactions of the Institute of British Geographers, 37(3), 386-401.

Roco, M. and Bainbridge, W., eds. 2002. Converging technologies for improving human performance. Arlington (VI): National Science Foundation.

Rose, N., 2007. The Politics of Life Itself. Princeton, NJ: Princeton University Press.

Samimian-Darash, T., 2011. Governing through time: preparing for future threats to health and security. Sociology of Health \& Illness, 33(6), 930-945.

Schlosberg, D. and Coles, R., 2016. The New environmentalism of everyday life: sustainability, material flows and movements. Contemporary Political Theory, 15(2), 160-181.

Selin, C., 2014. On not forgetting futures. Journal of Responsible Innovation, 1(1), 103-108.

Srnicek N. and Williams, A., 2015. Inventing the future. London: Verso.

Suskind, R., 2004. Without a doubt. The New York Times, October 17. Available from:

http://query.nytimes.com/gst/fullpage.html?res=9C05EFD8113BF934A25753C1A9629C8B63\& pagewanted=all [Accessed 11 January 2018].

Swyngedouw, E., 2010. Apocalypse forever? Post-political populism and the spectre of climate change. Theory, Culture \& Society, 27(2-3), 213-232.

Taubes, J. 2004. The Political Theology of Paul. Stanford, CA: Stanford University Press. Thacker, E., 2007. The Global Genome. Cambridge, MA: MIT Press.

Turnpenny, J.R. and Russel, D.J., 2017. The idea(s) of 'valuing nature': insights from the UK's ecosystem services framework. Environmental Politics, 26(6), 973-993. 
Vanloqueren, G. and Baret, P., 2009. How agricultural research systems shape a technological regime that develops genetic engineering but locks out agroecological innovations. Research Policy, 38, 971-983.

Virno, P., 2004. A grammar of the multitude. Los Angeles: Semiotext(e).

Von Schomberg, R. 2013. A vision of responsible research and innovation. In: R. Owen, J.

Bessant and M. Heintz, eds. Responsible Innovation. Chichester: Wiley, 51-74.

Walker, J. and Cooper, M., 2011. Genealogies of resilience. From systems ecology to the political economy of crisis adaptation. Security Dialogue 4(2), 143-160.

Williams A. and Srnicek, N., 2013. Manifesto for an accelerationist politics. Available at: http://criticallegalthinking.com/2013/05/14/accelerate-manifesto-for-an-accelerationist-politics/ [Accessed 20 December 2014].

Wright, E.O., 2010. Envisioning real utopias. London: Verso.

Yates, L., 2015. Rethinking prefiguration: alternatives, micropolitics and goals in social movements. Social Movement Studies, 14(1), 1-21,

Zwart, H., Lendeweerd, L. and van Rooij, A., 2014. Adapt or perish? Assessing the recent shift in the European research funding arena from 'ELSA' to 'RRI'. Life Sciences, Society and Policy, 10(11), 1-19. 